\title{
Post-treatment Glasgow Prognostic Score Predicts Efficacy in Advanced Non-small-cell Lung Cancer Treated With Anti-PD1
}

\author{
NORIMITSU KASAHARA ${ }^{1}$, NORIAKI SUNAGA ${ }^{2}$, YUSUKE TSUKAGOSHI ${ }^{2}$, YOSUKE MIURA $^{2}$, \\ REIKO SAKURAI ${ }^{3}$, SHINSUKE KITAHARA ${ }^{2}$, TAKEHIKO YOKOBORI ${ }^{4}$, KYOICHI KAIRA $^{5}$, \\ AKIRA MOGI $^{6}$, TOSHITAKA MAENO ${ }^{2}$, TAKAYUKI ASAO $^{1}$ and TAKESHI HISADA ${ }^{7}$ \\ ${ }^{1}$ Innovative Medical Research Center, Gunma University Hospital, Maebashi, Japan; \\ ${ }^{2}$ Department of Respiratory Medicine, Gunma University Graduate School of Medicine, Maebashi, Japan; \\ ${ }^{3}$ Oncology Center, Gunma University Hospital, Maebashi, Japan; \\ ${ }^{4}$ Department of Innovative Cancer Center Immunotherapy, Gunma University, Maebashi, Japan; \\ ${ }^{5}$ Department of Respiratory Medicine, Comprehensive Cancer Center, \\ International Medical Center, Saitama Medical University, Hidaka, Japan; \\ ${ }^{6}$ Department of General Surgical Science, Gunma University Graduate School of Medicine, Maebashi, Japan; \\ ${ }^{7}$ Gunma University, Graduate School of Health Sciences, Maebashi, Japan
}

\begin{abstract}
Background/Aim: No definitive biomarker exists for predicting treatment efficacy or response to therapy with antibody to programmed cell death-1 (PD1) for patients with advanced non-small cell lung cancer (NSCLC). Hence, we investigated whether the Glasgow prognostic score (GPS) predicted anti-PD1 treatment response for advanced NSCLC. Patients and Methods: This study retrospectively identified 47 patients with NSCLC treated with anti-PDI and assessed the prognostic value of the GPS. The GPS was calculated using $C$ reactive protein and albumin concentrations 1 month after starting anti-PD1 treatment. Kaplan-Meier method and Cox proportional hazard models were used to examine differences in progression-free (PFS) and overall (OS) survival, and clinical response. Results: The post-treatment GPS independently predicted anti-PDI treatment efficacy, as a good post-treatment GPS (GPS 0-1) was significantly associated with improved PFS. Intra-treatment GPS change was associated with clinical response. Conclusion: The post-treatment GPS independently predicted efficacy of anti-PDI treatment for NSCLC.
\end{abstract}

Lung cancer is the leading cause of cancer-related mortality worldwide (1); most cases are diagnosed at advanced or inoperable stages. Advanced cases often involve weight loss

Correspondence to: Norimitsu Kasahara, MD, Ph.D., Innovative Medical Research Center, Gunma University Hospital, 3-39-15, Showa-machi, Maebashi, Gunma 371-8511, Japan. Tel: +81 272208347, Fax: +81 272208347, e-mail: m14702016@gunma-u.ac.jp

Key Words: Glasgow prognostic score, anti-PD1, non-small cell lung cancer, immunotherapy, biomarker. and inflammatory response, with the magnitude of the systemic inflammatory response (SIR) predicting progression and survival in many cancer types (2-4). Thus, cancer-related prognosis is routinely examined using various SIR-based scoring systems, such as the neutrophil-to-lymphocyte ratio (NLR). The Glasgow prognostic score (GPS) is another SIRbased scoring system combining serum C-reactive protein (CRP) and albumin concentrations (5). The GPS is also an independent prognostic marker for advanced non-small cell lung cancer (NSCLC) (6-13).

Immune checkpoint inhibitors, such as antibodies to programmed cell death-1 (PD1) and programmed cell death ligand-1 (PD-L1) proteins, exhibit high clinical efficacy in several cancer types. Nivolumab and pembrolizumab are clinically approved antibodies targeting PD1; they are widely used for NSCLC treatment (14-17). Although immunohistochemistry-based tumor cell expression of PD-L1 is used to predict responses to anti-PD1/PD-L1 treatment, some patients respond to these treatments despite having low or no PD-L1 expression $(14,15)$. Moreover, anti-PD1/PD-L1 treatment is expensive and carries a risk of severe immune-related adverse events (18). Thus, early identification of patients who would respond to this treatment could help reduce the treatment cost and the risk of severe adverse outcomes. SIR-based markers can predict the response to immune checkpoint inhibitors, with the NLR predicting the response to immune checkpoint inhibitors in melanoma (19-21), renal cell carcinoma (22), and NSCLC (23-25). However, there is little information regarding the association between the GPS and the response to anti-PD1 treatment. Therefore, we investigated whether the posttreatment GPS is able to predict the response to anti-PD1 treatment in patients with advanced NSCLC. 
Table I. Patient characteristics.

\begin{tabular}{|c|c|c|c|c|c|c|}
\hline \multirow[b]{2}{*}{ Characteristic } & \multirow[b]{2}{*}{ Subgroup } & \multirow{2}{*}{$\begin{array}{l}\text { All patients } \\
\qquad \mathrm{N}=47\end{array}$} & \multicolumn{4}{|c|}{ Post-treatment GPS } \\
\hline & & & $0(\mathrm{~N}=24)$ & $1(\mathrm{~N}=6)$ & $2(\mathrm{~N}=17)$ & $p$-Value \\
\hline Age & $<65 / \geq 65$ years & $14 / 33$ & $9 / 15$ & $1 / 5$ & $4 / 13$ & 0.4736 \\
\hline Gender & $\mathrm{M} / \mathrm{F}$ & $37 / 10$ & $18 / 6$ & $4 / 2$ & $15 / 2$ & 0.4409 \\
\hline Stage & I-II/III-IV & $4 / 43$ & $2 / 22$ & $0 / 6$ & $2 / 15$ & 0.6736 \\
\hline Smoke & Ever/never & $42 / 5$ & $20 / 4$ & $5 / 1$ & $17 / 0$ & 0.2049 \\
\hline Pre-treatment, ECOG-PS & $0-1 / 2$ & $44 / 3$ & $22 / 2$ & $6 / 0$ & $16 / 1$ & 0.7524 \\
\hline Post-treatment, ECOG-PS & $0-1 / 2-4$ & $36 / 11$ & $20 / 4$ & $6 / 0$ & $10 / 7$ & 0.0660 \\
\hline Histology & $\mathrm{Sq} /$ non-Sq & $12 / 35$ & $1 / 23$ & $2 / 4$ & $9 / 8$ & 0.0018 \\
\hline Line of anti-PD1, therapy & $1-2 / \geq 3$ & $33 / 14$ & $16 / 8$ & $5 / 1$ & $12 / 5$ & 0.7264 \\
\hline Anti-PD1 treatment & Nivolumab/pembrolizumab & $36 / 11$ & $18 / 6$ & $5 / 1$ & $13 / 4$ & 0.9111 \\
\hline PD-L1 expression & $\geq 50 /<50 /$ unknown & $11 / 15 / 21$ & $6 / 6 / 12$ & $1 / 3 / 2$ & $4 / 6 / 7$ & 0.8178 \\
\hline Radiation therapy & Yes/no & $27 / 20$ & $15 / 9$ & $4 / 2$ & $8 / 9$ & 0.5461 \\
\hline
\end{tabular}

GPS: Glasgow prognostic score; N: number of patients; ECOG PS: Eastern Cooperative Oncology Group Performance Status; Sq: squamous cell carcinoma; PD1: programmed cell death-1; PD-L1: programmed cell death ligand-1.

\section{Patients and Methods}

Patients. This retrospective study evaluated consecutive patients with histologically or cytologically diagnosed NSCLC who had received anti-PD1 treatment (nivolumab or pembrolizumab) at Gunma University Hospital between January 2016 and June 2018. Serum CRP and albumin concentrations were measured before and 1 month after treatment initiation. The GPS was defined as: 0: CRP $<10 \mathrm{mg} / \mathrm{l}$ and albumin $>35 \mathrm{~g} / \mathrm{l} ; 1$ : CRP $\geq 10 \mathrm{mg} / \mathrm{I}$ or albumin $<35$ $\mathrm{g} / \mathrm{l}$; or 2 : CRP $>10 \mathrm{mg} / \mathrm{l}$ and albumin $<35 \mathrm{~g} / \mathrm{l}$. The NLR was defined as the ratio of absolute neutrophil and absolute lymphocyte counts; the NLR cut-off value was set at $5(23,26)$.

The study protocol was approved by the Institutional Review Board of Gunma University Hospital (2018-186), and followed the guidelines of the Helsinki Declaration. Adverse events were graded using the Common Terminology Criteria for Adverse Events (version 4.0) (27). Objective tumor responses were evaluated according to the Response Evaluation Criteria in Solid Tumors (version 1.1) (28). For immunohistochemical analysis, PD-L1 expression was studied using an antibody against PD-L1 protein (22C3 pharmDx; Dako, Glostrup, Denmark). The follow-up duration for censored cases was 4.13-31.8 months (median=14.7 months).

Statistical analysis. Continuous and categorical variables were analyzed using Student's $t$-test and chi-squared test, respectively. The relationships between different variables or matched pairs were examined using the non-parametric Spearman rank test or Wilcoxon signed-rank test, as appropriate. The Kaplan-Meier method and logrank test were used to compare differences in patient survival. Progression-free survival (PFS) was recorded as the time between initiation of anti-PD1 treatment to the first instance of disease relapse, death, or the last follow-up visit with no evidence of relapse. Overall survival (OS) was measured as the interval from anti-PD1 treatment initiation to death from any cause. Univariate and multivariate analyses were performed using Cox's proportional hazard models for survival. Differences were considered significant at $p$-values of less than 0.05; all analyses were performed using JMP Pro software (version 12.0; SAS Institute Inc., Cary, NC, USA).

\section{Results}

Patient demographics. The present study included 47 patients with advanced NSCLC (37 men; 10 women); their demographic characteristics are shown in Table I. At antiPD1 treatment initiation, the median age was 69 years (range $=48-81$ years); 42 patients were smokers. The study group included 31 patients with adenocarcinoma, 12 with squamous cell carcinoma, three with poorly differentiated carcinoma, and one with adenosquamous carcinoma. Prior to anti-PD1 treatment, 27 patients received radiation therapy. Two patients had epidermal growth factor receptor mutations, and one patient showed anaplastic lymphoma kinase rearrangements. All patients received single-agent immunotherapy, with 36 patients receiving nivolumab (median $=6$ cycles, range $=1-60$ cycles) and 11 patients receiving pembrolizumab (median $=3$ cycles, range $=1-22$ cycles). After 1 month of PD1 treatment, the GPS was 0,1 , and 2 for 24, 6, and 17 patients, respectively; the Eastern Cooperative Oncology Group Performance Status (ECOGPS) of patients was 0-1 in 36 patients, 2 in six patients, 3 in three patients, and 4 in two patients.

Association between the GPS and response to anti-PDI treatment. The median PFS for the whole patient cohort was 4.9 months (95\% confidence interval $(\mathrm{CI})=1.9-7.6$ months); 34 patients experienced disease progression. Tables II-IV show the results of univariate and multivariate analyses for PFS, OS, and clinical response. Univariate analyses revealed significant differences in PFS according to the post-treatment ECOG-PS, GPS, and NLR. However, multivariate analyses revealed that the post-treatment GPS was the sole independent predictor of a short PFS (hazard ratio $(\mathrm{HR})=0.45, p=0.04$ ) (Table II). The Kaplan-Meier curves for PFS according to post-treatment GPS 
Table II. Analysis of factors for association with progression-free survival (PFS) after anti-programmed cell death-1 (PD1) therapy.

\begin{tabular}{|c|c|c|c|c|c|}
\hline \multirow[b]{2}{*}{ Characteristic } & \multirow[b]{2}{*}{ Subgroup } & \multicolumn{4}{|c|}{ HR for PFS $(95 \% \mathrm{CI})$} \\
\hline & & Univariate & $p$-Value & Multivariate & $p$-Value \\
\hline Age & $<65 / \geq 65$ years & $1.04(0.49-2.09)$ & 0.92 & & \\
\hline Gender & $\mathrm{M} / \mathrm{F}$ & $0.61(0.29-1.38)$ & 0.22 & & \\
\hline Smoke & Ever/never & $0.53(0.22-1.57)$ & 0.23 & & \\
\hline Histology & $\mathrm{Sq} / \mathrm{nonSq}$ & $0.94(0.37-2.06)$ & 0.88 & & \\
\hline Line of therapy & $1-2 / \geq 3$ & $0.50(0.25-1.04)$ & 0.06 & & \\
\hline Radiation herapy & Yes/no & $0.730 .37-1.45)$ & 0.36 & & \\
\hline Pre-ECOG-PS & $0-1 / 2-4$ & $0.55(0.19-2.31)$ & 0.36 & & \\
\hline Pre-GPS & $0-1 / 2$ & $0.81(0.40-1.74)$ & 0.57 & & \\
\hline Pre-NLR & High/low & $0.80(0.40-1.57)$ & 0.52 & & \\
\hline Post-ECOG-PS & $0-1 / 2-4$ & $0.42(0.20-0.92)$ & 0.03 & $0.55(0.25-1.29)$ & 0.16 \\
\hline Post-GPS & $0-1 / 2$ & $0.36(0.18-0.75)$ & $<0.01$ & $0.45(0.21-0.99)$ & 0.04 \\
\hline Post-NLR & High/low & $3.30(1.46-7.26)$ & $<0.01$ & $2.12(0.85-5.13)$ & 0.11 \\
\hline
\end{tabular}

HR: Hazard ratio; Sq: squamous cell carcinoma; ECOG PS: Eastern Cooperative Oncology Group Performance Status; GPS: Glasgow prognostic score; NLR: neutrophil-to-lymphocyte ratio; Pre: before anti-PD1 therapy; Post: after anti-PD1 therapy.

are shown in Figure 1, with a GPS of 0 -1 being associated with significantly longer PFS than a GPS of $2(p<0.01)$. The median OS for the whole patient cohort was 19.7 months $(95 \%$ $\mathrm{CI}=10.0$ months to not reached); 22 patients eventually died. Based on the post-treatment ECOG-PS and GPS, univariate analyses revealed significant differences in OS. Multivariate analyses showed that both these markers independently predicted a short $\mathrm{OS}(\mathrm{HR}=0.15, p<0.01 ; \mathrm{HR}=0.18, p<0.01$, respectively; Table III). The Kaplan-Meier curves for OS according to post-treatment GPS are presented in Figure 1, showing a GPS of $0-1$ to be associated with significantly longer OS than GPS of $2(p<0.01)$.

Twelve out of the 47 patients (33.3\%) exhibited an objective clinical response to anti-PD1 treatment. Univariate analyses revealed that treatment response was associated with a low post-treatment GPS and low post-treatment NLR (Table IV). Although the post-treatment GPS was marginally associated with treatment response, only the post-treatment NLR was a significant predictor of treatment response (odds ratio $=0.16, p=0.05$ ) (Table IV); it was not possible to calculate the HR because none of the patients with a high NLR exhibited a clinical response. The pre-treatment PS, pre-treatment GPS, and pre-treatment NLR values were not associated with PFS, OS, or clinical response (Tables II-IV).

Changes in GPS during anti-PD1 treatment. Figure 2 shows the changes in GPS during anti-PD1 treatment. Among 12 patients with an objective clinical response, six patients (50\%) showed an improved GPS, six (50\%) maintained a stable GPS, and there were no patients whose GPS deteriorated $(p=0.03)$. Among 20 patients who experienced disease progression, we found one patient with improved GPS (5\%), 12 with a stable GPS (60\%), and seven with a worsened GPS $(35 \%)(p=0.04)$. Patients with stable disease did not exhibit a significant change in their GPS $(p=0.48)$.

\section{Discussion}

To the best of our knowledge, this is the first study examining the relationship between GPS and efficacy of anti-PD1 treatment. One month after starting anti-PD1 treatment, the GPS was significantly associated with both PFS and OS, while the post-treatment GPS was marginally associated with response to anti-PD1 treatment. Thus, the post-treatment GPS may be useful for early prediction of a patient's response to anti-PD1 treatment and their subsequent prognosis.

The GPS has prognostic value in lung cancer, independently of tumor stage and conventional prognostic markers (6-13). The GPS is also associated with elevated cytokine and adipokine levels, drug metabolism, weight and muscle loss, and poor PS (4, 29-35). These factors are associated with the host immune status and may influence the efficacy of anti-PD1 treatment. Furthermore, the GPS is calculated using serum CRP and albumin concentrations; this test is feasible and associated with a minimal cost at most institutions. Moreover, the assessment of the GPS is more objective compared to the conventional prognostic factor ECOG-PS (36). Therefore, it appears reasonable to consider the use of the GPS in clinical practice.

Several studies have investigated biomarkers that can predict the response to immune checkpoint inhibitors (37). For example, the pre-treatment NLR may predict the prognosis of patients with NSCLC treated with nivolumab (23); however, the present study revealed that the pre-treatment GPS and NLR values were not associated with the efficacy of anti-PD1 treatment (Table II). Previously, the post-treatment not the pretreatment NLR was associated with the efficacy of anti-PD1 
Table III. Analysis of factors for association with overall (OS) survival after anti-programmed cell death-1 (PD1) therapy.

\begin{tabular}{|c|c|c|c|c|c|}
\hline \multirow[b]{2}{*}{ Characteristic } & \multirow[b]{2}{*}{ Subgroup } & \multicolumn{4}{|c|}{ HR for OS $(95 \% \mathrm{CI})$} \\
\hline & & Univariate & $p$-Value & Multivariate & $p$-Value \\
\hline Age & $<65 / \geq 65$ years & $1.28(0.51-3.03)$ & 0.59 & & \\
\hline Gender & $\mathrm{M} / \mathrm{F}$ & $0.93(0.34-3.24)$ & 0.89 & & \\
\hline Smoke & Ever/never & $1.08(0.31-6.81)$ & 0.91 & & \\
\hline Histology & $\mathrm{Sq} / \mathrm{nonSq}$ & $2.53(0.93-6.37)$ & 0.07 & & \\
\hline Line of therapy & $1-2 / \geq 3$ & $0.52(0.22-1.28)$ & 0.15 & & \\
\hline Radiation therapy & Yes/no & $1.20(0.51-2.92)$ & 0.68 & & \\
\hline Pre-ECOG-PS & $0-1 / 2-4$ & $0.33(0.11-1.44)$ & 0.12 & & \\
\hline Pre-GPS & $0-1 / 2$ & $0.43(0.18-1.02)$ & 0.05 & & \\
\hline Pre-NLR & High/low & $1.82(0.72-4.67)$ & 0.18 & & \\
\hline Post-ECOG-PS & $0-1 / 2-4$ & $0.16(0.07-0.42)$ & $<0.01$ & $0.15(0.06-0.42)$ & $<0.01$ \\
\hline Post-GPS & $0-1 / 2$ & $0.19(0.07-0.47)$ & $<0.01$ & $0.18(0.06-0.48)$ & $<0.01$ \\
\hline Post-NLR & High/low & $2.94(0.99-7.92)$ & 0.05 & & \\
\hline
\end{tabular}

HR: Hazard ratio; Sq: squamous cell carcinoma; ECOG-PS: Eastern Cooperative Oncology Group Performance Status; GPS: Glasgow prognostic score; NLR: neutrophil-to-lymphocyte ratio; Pre: before anti-PD1 therapy; Post: after anti-PD1 therapy.

Table IV. Analysis of factors for association with response to anti-programmed cell death-1 (PD1) therapy.

\begin{tabular}{|c|c|c|c|c|c|}
\hline \multirow[b]{2}{*}{ Characteristic } & \multirow[b]{2}{*}{ Subgroups } & \multicolumn{4}{|c|}{ OR for response $(95 \% \mathrm{CI})$} \\
\hline & & Univariate & $p$-Value & Multivariate & $p$-Value \\
\hline Age & $<65 / \geq 65$ years & $1.38(0.33-7.10)$ & 0.67 & & \\
\hline Gender & $\mathrm{M} / \mathrm{F}$ & $0.68(0.09-3.29)$ & 0.64 & & \\
\hline Smoke & Ever/never & $<0.01(<0.01-1.28)$ & 0.08 & & \\
\hline Histology & $\mathrm{Sq} /$ nonSq & $5.04(0.81-97.94)$ & 0.09 & & \\
\hline Line of therapy & $1-2 / \geq 3$ & $0.38(0.05-1.76)$ & 0.23 & & \\
\hline Radiation herapy & Yes/No & $0.95(0.24-3.58)$ & 0.94 & & \\
\hline Pre-ECOG-PS & $0-1 / 2-4$ & $1.5(0.07-17.19)$ & 0.76 & & \\
\hline Pre-GPS & $0-1 / 2$ & $1.79(0.44-7.01)$ & 0.41 & & \\
\hline Pre-NLR & High/low & $0.79(0.18-4.24)$ & 0.77 & & \\
\hline Post-ECOG-PS & $0-1 / 2-4$ & $0.58(0.08-2.76)$ & 0.51 & & \\
\hline Post-GPS & $0-1 / 2$ & $0.11(<0.01-0.65)$ & 0.01 & $0.16(<0.01-1.03)$ & 0.05 \\
\hline Post-NLR & High/low & - & $<0.01$ & - & 0.02 \\
\hline
\end{tabular}

OR: Odds ratio; Sq: squamous cell carcinoma; ECOG-PS: Eastern Cooperative Oncology Group Performance Status; GPS: Glasgow prognostic score; NLR: neutrophil-to-lymphocyte ratio; Pre: before anti-PD1 therapy; Post: after anti-PD1 therapy.

treatment (24); this highlights the challenges associated with early identification of patients who will respond better to antiPD1 treatment. Nevertheless, the present study revealed that early evaluation of post-treatment GPS (after 1 month of treatment) was able to predict the efficacy of anti-PD1 treatment; furthermore, multivariate analyses demonstrated that the post-treatment GPS was better than the post-treatment NLR to predict PFS due to anti-PD1 treatment. Moreover, the current study revealed significant changes in the GPS during treatment of patients who had experienced a partial response or disease progression (Figure 2). Therefore, early evaluation of any change in the GPS may help in distinguishing between patients who will experience a clinical response, have stable disease, or experience true disease progression. However, further studies are needed to examine the predictive value of the post-treatment GPS in clinical settings.

This study has several limitations. Firstly, the study used a single-center retrospective protocol, prone to institutional biases and differences in the timing of evaluations made by clinicians. SecondIy, the sample size was small; it was difficult to address this because of i) the relatively recent approval of anti-PD1 therapy; and ii) the single-center retrospective nature of this study. Lastly, almost half of the patients did not undergo PD-L1 testing (21/47, 45\%); this was owing to the lack of routine PD-L1 testing for patients with NSCLC at our institution, resulting in the exclusion of 
A

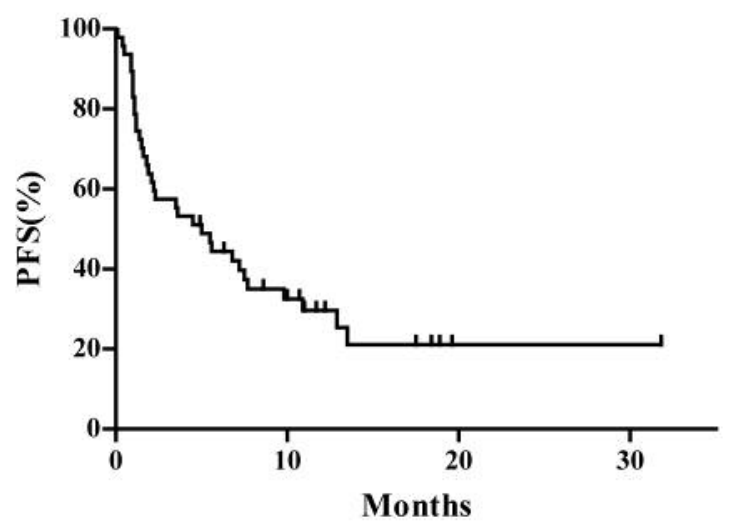

$\mathrm{C}$

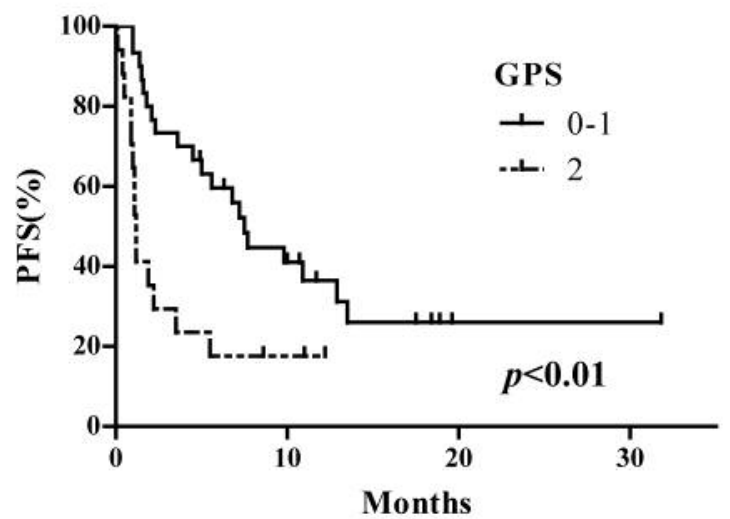

B

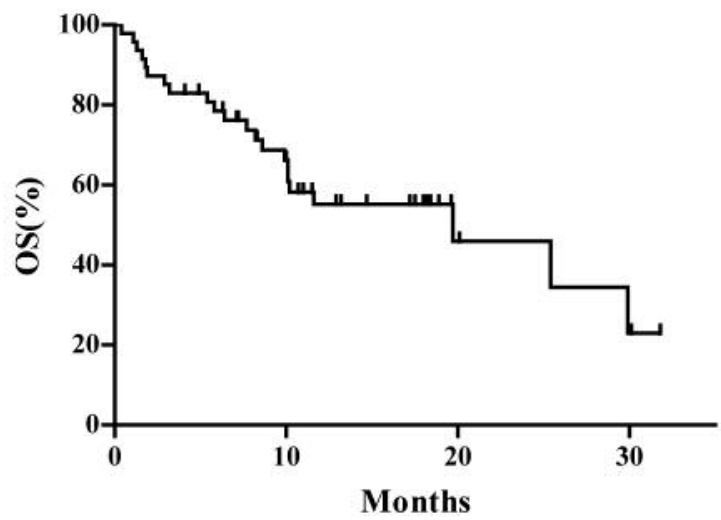

$\mathrm{D}$

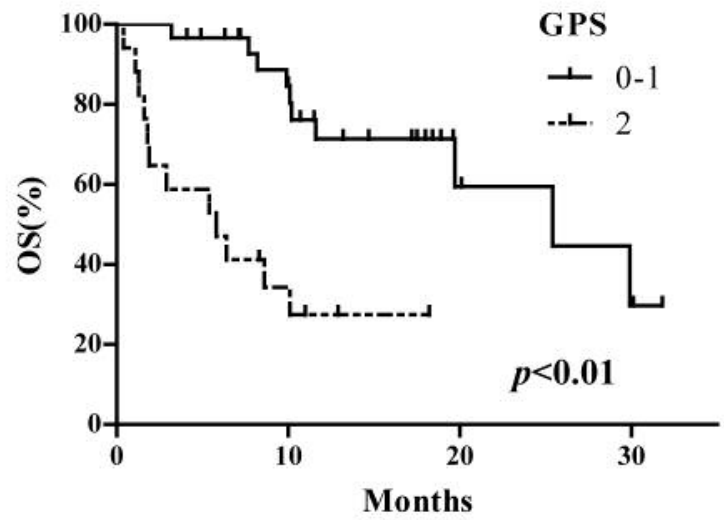

Figure 1. Kaplan-Meier curves for progression-free (PFS) and overall (OS) survival of all patients (A and B, respectively) and according to the post-treatment Glasgow prognostic score (GPS) (C and D, respectively).

A

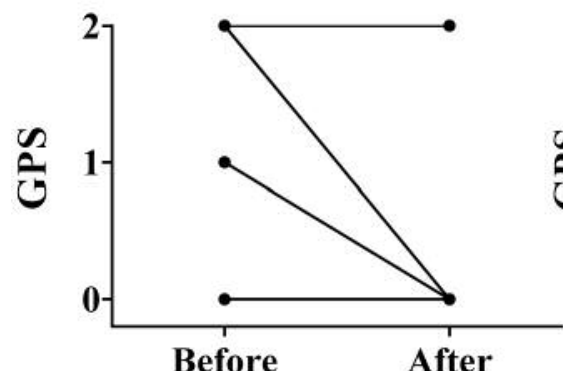

Decrease 6, no change 6, increase 0
B

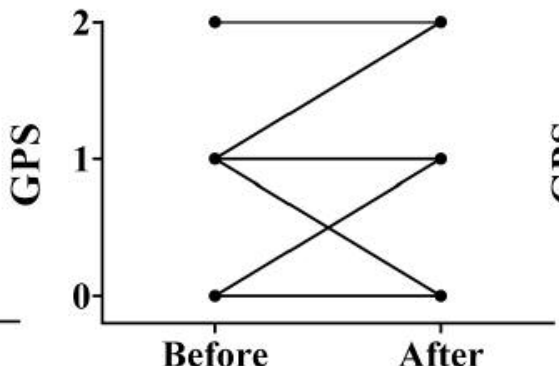

Decrease 2, no change 9, increase 4
$\mathrm{C}$ $p=0.04$

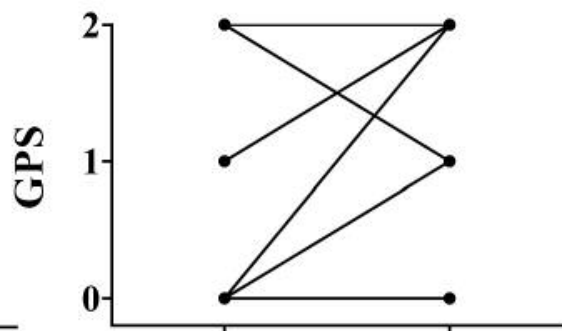

Before
After

Figure 2. Changes in the Glasgow prognostic score (GPS) during treatment with an antibody to programmed cell death-1 (PD1). The changes from the pre-treatment GPS to post-treatment GPS are shown for patients with a partial response (PR, panel A), stable disease (SD, panel B) and progressive disease $(P D$, panel $C)$. p-Values were calculated using the Wilcoxon signed-rank test. 
this variable from our analyses. Hence, well-designed prospective studies are needed.

In conclusion, the post-treatment GPS at 1 month was able to predict both the efficacy and clinical response to anti-PD1 treatment in patients with NSCLC. Although further studies are warranted to validate these findings, our results suggest that determination of early post-treatment GPS may help in better managing patients with NSCLC receiving anti-PD1 treatment.

\section{Conflicts of Interest}

The Authors declare no conflicts of interest associated with this study.

\section{Authors' Contributions}

NK designed the study and wrote the article. NS, TY, and TA helped design the study. YT, YM, RS, SK, KK, AM, and TM contributed to the clinical treatment. TH takes responsibilifigty for accuracy of this study.

\section{References}

1 Siegel RL, Miller KD and Jemal A: Cancer statistics, 2015. CA Cancer J Clin 65(1): 5-29, 2015. PMID: 25559415. DOI: $10.3322 /$ caac. 21254 .

2 Coussens LM and Werb Z: Inflammation and cancer. Nature 420(6917): 860-867, 2002. PMID: 12490959. DOI: 10.1038/ nature01322.

3 Mantovani A, Romero P, Palucka AK and Marincola FM: Tumour immunity: Effector response to tumour and role of the microenvironment. Lancet 371(9614): 771-783, 2008. PMID: 18275997. DOI: 10.1016/S0140-6736(08)60241-X.

4 Proctor MJ, Talwar D, Balmar SM, O'Reilly DS, Foulis AK, Horgan PG, Morrison DS and McMillan DC: The relationship between the presence and site of cancer, an inflammation-based prognostic score and biochemical parameters. Initial results of the Glasgow Inflammation Outcome Study. Br J Cancer 103(6): 870-876, 2010. PMID: 20717110. DOI: 10.1038/sj.bjc.6605855.

5 McMillan DC: An inflammation-based prognostic score and its role in the nutrition-based management of patients with cancer. Proc Nutr Soc 67(3): 257-262, 2008. PMID: 18452641. DOI: 10.1017/S0029665108007131.

6 Forrest LM, McMillan DC, McArdle CS, Angerson WJ and Dunlop DJ: Comparison of an inflammation-based prognostic score (GPS) with performance status (ECOG) in patients receiving platinum-based chemotherapy for inoperable nonsmall-cell lung cancer. Br J Cancer 90(9): 1704-1706, 2004. PMID: 15150622 . DOI: $10.1038 /$ sj.bjc.6601789.

7 Gioulbasanis I, Pallis A, Vlachostergios PJ, Xyrafas A, Giannousi Z, Perdikouri IE, Makridou M, Kakalou D and Georgoulias V: The Glasgow Prognostic Score (GPS) predicts toxicity and efficacy in platinum-based treated patients with metastatic lung cancer. Lung Cancer 77(2): 383-388, 2012. PMID: 22551892. DOI: 10.1016/j.lungcan.2012.04.008.

8 Umihanic S, Umihanic S, Jamakosmanovic S, Brkic S, Osmic M, Dedic S and Ramic N: Glasgow prognostic score in patients receiving chemotherapy for non-small-cell lung cancer in stages IIIb and IV. Med Arch 68(2): 83-85, 2014. PMID: 24937927. DOI: $10.5455 /$ medarh.2014.68.83-85.
9 Jiang AG, Chen HL and Lu HY: Comparison of Glasgow prognostic score and prognostic index in patients with advanced non-small cell lung cancer. J Cancer Res Clin Oncol 141(3): 563568, 2015. PMID: 25257958. DOI: 10.1007/s00432-014-1839-4.

10 Zhu L, Li X, Shen Y, Cao Y, Fang X, Chen J and Yuan Y: A new prognostic score based on the systemic inflammatory response in patients with inoperable non-small-cell lung cancer. Onco Targets Ther 9: 4879-4886, 2016. PMID: 27540301. DOI: 10.2147/OTT.S107279.

11 Simmons CP, Koinis F, Fallon MT, Fearon KC, Bowden J, Solheim TS, Gronberg BH, McMillan DC, Gioulbasanis I and Laird BJ: Prognosis in advanced lung cancer - a prospective study examining key clinicopathological factors. Lung Cancer 88(3): 304-309, 2015. PMID: 25870155. DOI: 10.1016/ j.lungcan.2015.03.020.

12 Minami S, Ihara S, Kim SH, Yamamoto S and Komuta K: Lymphocyte to monocyte ratio and modified Glasgow prognostic score predict prognosis of lung adenocarcinoma without driver mutation. World J Oncol 9(1): 13-20, 2018. PMID: 29581811. DOI: $10.14740 /$ wjon 1084 w.

13 Leung EY, Scott HR and McMillan DC: Clinical utility of the pretreatment Glasgow prognostic score in patients with advanced inoperable non-small cell lung cancer. J Thorac Oncol 7(4): 655-662, 2012. PMID: 22425914. DOI: 10.1097/ JTO.0b013e 318244ffe1.

14 Brahmer J, Reckamp KL, Baas P, Crino L, Eberhardt WE, Poddubskaya E, Antonia S, Pluzanski A, Vokes EE, Holgado E, Waterhouse D, Ready N, Gainor J, Aren Frontera O, Havel L, Steins M, Garassino MC, Aerts JG, Domine M, Paz-Ares L, Reck M, Baudelet C, Harbison CT, Lestini B and Spigel DR: Nivolumab versus docetaxel in advanced squamous-cell nonsmall-cell lung cancer. N Engl J Med 373(2): 123-135, 2015. PMID: 26028407. DOI: 10.1056/NEJMoa1504627.

15 Borghaei H, Paz-Ares L, Horn L, Spigel DR, Steins M, Ready NE, Chow LQ, Vokes EE, Felip E, Holgado E, Barlesi F, Kohlhaufl M, Arrieta O, Burgio MA, Fayette J, Lena H, Poddubskaya E, Gerber DE, Gettinger SN, Rudin CM, Rizvi N, Crino L, Blumenschein GR Jr., Antonia SJ, Dorange C, Harbison $\mathrm{CT}$, Graf Finckenstein $\mathrm{F}$ and Brahmer JR: Nivolumab versus docetaxel in advanced nonsquamous non-small-cell lung cancer. N Engl J Med 373(17): 1627-1639, 2015. PMID: 26412456. DOI: $10.1056 /$ NEJMoa1507643.

16 Reck M, Rodriguez-Abreu D, Robinson AG, Hui R, Csoszi T, Fulop A, Gottfried M, Peled N, Tafreshi A, Cuffe S, O'Brien M, Rao S, Hotta K, Leiby MA, Lubiniecki GM, Shentu Y, Rangwala $\mathrm{R}$, and Brahmer JR: Pembrolizumab versus chemotherapy for PD-L1-positive non-small-cell lung cancer. N Engl J Med 375(19): 1823-1833, 2016. PMID: 27718847. DOI: 10.1056/NEJMoa1606774.

17 Herbst RS, Baas P, Kim DW, Felip E, Perez-Gracia JL, Han JY, Molina J, Kim JH, Arvis CD, Ahn MJ, Majem M, Fidler MJ, de Castro G Jr., Garrido M, Lubiniecki GM, Shentu Y, Im E, Dolled-Filhart $\mathrm{M}$ and Garon EB: Pembrolizumab versus docetaxel for previously treated, PD-L1-positive, advanced nonsmall-cell lung cancer (KEYNOTE-010): A randomised controlled trial. Lancet 387(10027): 1540-1550, 2016. PMID: 26712084. DOI: 10.1016/S0140-6736(15)01281-7.

18 Eigentler TK, Hassel JC, Berking C, Aberle J, Bachmann O, Grunwald V, Kahler KC, Loquai C, Reinmuth N, Steins M, Zimmer L, Sendl A and Gutzmer R: Diagnosis, monitoring and management of immune-related adverse drug reactions of antiPD1 antibody therapy. Cancer Treat Rev 45: 7-18, 2016. PMID: 26922661. DOI: 10.1016/j.ctrv.2016.02.003. 
19 Ferrucci PF, Gandini S, Battaglia A, Alfieri S, Di Giacomo AM, Giannarelli D, Cappellini GC, De Galitiis F, Marchetti P, Amato G, Lazzeri A, Pala L, Cocorocchio E and Martinoli C: Baseline neutrophil-to-lymphocyte ratio is associated with outcome of ipilimumab-treated metastatic melanoma patients. Br J Cancer 112(12): 1904-1910, 2015. PMID: 26010413. DOI: 10.1038/ bjc. 2015.180 .

20 Ferrucci PF, Ascierto PA, Pigozzo J, Del Vecchio M, Maio M, Antonini Cappellini GC, Guidoboni M, Queirolo P, Savoia P, Mandala M, Simeone E, Valpione S, Altomonte M, Spagnolo F, Cocorocchio E, Gandini S, Giannarelli D and Martinoli C: Baseline neutrophils and derived neutrophil-to-lymphocyte ratio: Prognostic relevance in metastatic melanoma patients receiving ipilimumab. Ann Oncol 27(4): 732-738, 2016. PMID: 26802161. DOI: 10.1093/annonc/mdw016.

21 Capone M, Giannarelli D, Mallardo D, Madonna G, Festino L, Grimaldi AM, Vanella V, Simeone E, Paone M, Palmieri G, Cavalcanti E, Caraco C and Ascierto PA: Baseline neutrophilto-lymphocyte ratio (NLR) and derived NLR could predict overall survival in patients with advanced melanoma treated with nivolumab. J Immunother Cancer 6(1): 74, 2018. PMID: 30012216. DOI: 10.1186/s40425-018-0383-1.

22 Jeyakumar G, Kim S, Bumma N, Landry C, Silski C, Suisham S, Dickow B, Heath E, Fontana $J$ and Vaishampayan U: Neutrophil lymphocyte ratio and duration of prior antiangiogenic therapy as biomarkers in metastatic RCC receiving immune checkpoint inhibitor therapy. J Immunother Cancer 5(1): 82, 2017. PMID: 29041991. DOI: 10.1186/s40425-017-0287-5.

23 Bagley SJ, Kothari S, Aggarwal C, Bauml JM, Alley EW, Evans TL, Kosteva JA, Ciunci CA, Gabriel PE, Thompson JC, Stonehouse-Lee S, Sherry VE, Gilbert E, Eaby-Sandy B, Mutale F, DiLullo G, Cohen RB, Vachani A and Langer CJ: Pretreatment neutrophil-to-lymphocyte ratio as a marker of outcomes in nivolumab-treated patients with advanced nonsmall-cell lung cancer. Lung Cancer 106: 1-7, 2017. PMID: 28285682. DOI: 10.1016/j.lungcan.2017.01.013.

24 Suh KJ, Kim SH, Kim YJ, Kim M, Keam B, Kim TM, Kim DW, Heo DS and Lee JS: Post-treatment neutrophil-to-lymphocyte ratio at week 6 is prognostic in patients with advanced non-small cell lung cancers treated with anti-PD1 antibody. Cancer Immunol Immunother 67(3): 459-470, 2018. PMID: 29204702. DOI: $10.1007 / \mathrm{s} 00262-017-2092-x$.

25 Mezquita L, Auclin E, Ferrara R, Charrier M, Remon J, Planchard D, Ponce S, Ares LP, Leroy L, Audigier-Valette C, Felip E, ZeronMedina J, Garrido P, Brosseau S, Zalcman G, Mazieres J, Caramela C, Lahmar J, Adam J, Chaput N, Soria JC and Besse B: Association of the lung immune prognostic index with immune checkpoint inhibitor outcomes in patients with advanced nonsmall cell lung cancer. JAMA Oncol 4(3): 351-357, 2018. PMID: 29327044. DOI: 10.1001/jamaoncol.2017.4771.

26 Guthrie GJ, Charles KA, Roxburgh CS, Horgan PG, McMillan DC and Clarke SJ: The systemic inflammation-based neutrophillymphocyte ratio: Experience in patients with cancer. Crit Rev Oncol Hematol 88(1): 218-230, 2013. PMID: 23602134. DOI: 10.1016/j.critrevonc.2013.03.010.

27 National Cancer Institute: Common Terminology Criteria for Adverse Events v.3.0and v.4.0 (CTCAE). Available at: http://ctep. cancer.gov/protocolDevelopment/electronic_applications/ctc.htm.
28 Therasse P, Arbuck SG, Eisenhauer EA, Wanders J, Kaplan RS, Rubinstein L, Verweij J, Van Glabbeke M, van Oosterom AT, Christian MC and Gwyther SG: New guidelines to evaluate the response to treatment in solid tumors. European Organization for Research and Treatment of Cancer, National Cancer Institute of the United States, National Cancer Institute of Canada. J Natl Cancer Inst 92(3): 205-216, 2000. PMID: 10655437. DOI: 10.1093/jnci/92.3.205.

29 Brown DJ, Milroy R, Preston T and McMillan DC: The relationship between an inflammation-based prognostic score (Glasgow Prognostic Score) and changes in serum biochemical variables in patients with advanced lung and gastrointestinal cancer. J Clin Pathol 60(6): 705-708, 2007. PMID: 16644880. DOI: $10.1136 /$ jcp.2005.033217.

$30 \mathrm{Kim}$ SJ, Ryu KJ, Hong M, Ko YH and Kim WS: The serum CXCL13 level is associated with the Glasgow prognostic score in extranodal NK/T-cell lymphoma patients. J Hematol Oncol 8: 49, 2015. PMID: 25966773. DOI: 10.1186/s13045-015-0142-4.

31 McMillan DC: The systemic inflammation-based Glasgow prognostic score: A decade of experience in patients with cancer. Cancer Treat Rev 39(5): 534-540, 2013. PMID: 22995477. DOI: $0.1016 /$ j.ctrv.2012.08.003.

32 Naito T, Tashiro M, Ishida T, Ohnishi $\mathrm{K}$ and Kawakami J: Cancer cachexia raises the plasma concentration of oxymorphone through the reduction of CYP3A but not CYP2D6 in oxycodone-treated patients. J Clin Pharmacol 53(8): 812-818, 2013. PMID: 23733622. DOI: 10.1002/jcph.112.

33 Kerem M, Ferahkose Z, Yilmaz UT, Pasaoglu H, Ofluoglu E, Bedirli A, Salman B, Sahin TT and Akin M: Adipokines and ghrelin in gastric cancer cachexia. World J Gastroenterol 14(23): 3633-3641, 2008. PMID: 18595130. DOI: 10.3748/wjg.14.3633.

34 Giannousi Z, Gioulbasanis I, Pallis AG, Xyrafas A, Dalliani D, Kalbakis K, Papadopoulos V, Mavroudis D, Georgoulias V and Papandreou CN: Nutritional status, acute-phase response and depression in metastatic lung cancer patients: Correlations and association prognosis. Support Care Cancer 20(8): 1823-1829, 2012. PMID: 21959842. DOI: 10.1007/s00520-011-1282-x.

35 Naito T, Tashiro M, Yamamoto K, Ohnishi K, Kagawa Y and Kawakami J: Impact of cachexia on pharmacokinetic disposition of and clinical responses to oxycodone in cancer patients. Eur J Clin Pharmacol 68(10): 1411-1418, 2012. PMID: 22441315. DOI: $10.1007 / \mathrm{s} 00228-012-1266-x$.

36 Dajczman E, Kasymjanova G, Kreisman H, Swinton N, Pepe C and Small D: Should patient-rated performance status affect treatment decisions in advanced lung cancer? J Thorac Oncol 3(10): 1133-1136, 2008. PMID: 18827609. DOI: 10.1097/ JTO.0b013e318186a272.

37 Shien K, Papadimitrakopoulou VA and Wistuba II: Predictive biomarkers of response to PD1/PD11 immune checkpoint inhibitors in non-small cell lung cancer. Lung Cancer 99: 79-87, 2016. PMID: 27565919. DOI: 10.1016/j.lungcan.2016.06.016.

Received January 22, 2019

Revised February 4, 2019

Accepted February 7, 2019 